\title{
Design, Microwave Assisted Synthesis of Some Schiff Bases Derivatives of Congo Red and Conventional Preparation of Their Structurally Reversed Analogous Compounds
}

\author{
Nashwan 0. Tapabashi' ${ }^{1}$, Nihad I. Taha1, Marwa El-Subeyhi² \\ ${ }^{1}$ Collage of Pharmacy, University of Kirkuk, Kirkuk, IRAQ \\ ${ }^{2}$ Collage of Science, University of Anbar, Ramadi, IRAQ \\ Email: dr.nashwanomer@uokirkuk.edu.iq,nihad.ismael@uokirkuk.edu.iq,marwa.noori@uoanber.edu.iq
}

How to cite this paper: Tapabashi, N.O., Taha, N.I. and El-Subeyhi, M. (2021) Design, Microwave Assisted Synthesis of Some Schiff Bases Derivatives of Congo Red and Conventional Preparation of Their Structurally Reversed Analogous Compounds. International Journal of Organic Chemistry, 11, 35-45.

https://doi.org/10.4236/ijoc.2021.111004

Received: January 7, 2021

Accepted: March 6, 2021

Published: March 9, 2021

Copyright $\odot 2021$ by author(s) and Scientific Research Publishing Inc. This work is licensed under the Creative Commons Attribution International License (CC BY 4.0).

http://creativecommons.org/licenses/by/4.0/

\begin{abstract}
This work contributes to the improvement of the azo group which has outstanding electron donating capability and serves as excellent ligands in the field of coordination chemistry. The authors of this research deal with the microwave irradiation synthesis of some new Schiff bases derived from the biologically effective and photoactive Congo red [Ia-g]. The design and preparation of the structurally reversed analogous compounds to the above compounds [IIIa-d] were accomplished using the conventional chemical methods by keeping the benzidine moiety of Congo red as the nucleus of the synthesized compounds, doubling the number of the azo groups and inverting the way of their conjugation order with the azomethine groups. The structures of the newly prepared compounds were established on the basis of their FTIR and $\mathrm{H}^{1} \mathrm{NMR}$ spectral data.
\end{abstract}

\section{Keywords}

Azo-Schiff, Congo Red, Diazonium Salt, Photochemical Conversion, Dye Sensitized Solar Cell

\section{Introduction}

Azo compounds with bacterial [1] [2], pesticidal [3], antifungal [4] and other biological activities have important role as colorant in textile industry [5]. And despite the toxicity of some of them, dozens of monoazo dyes are applied in cosmetics and drugs [6]. Moreover the azo group has outstanding electron donating capability which enables it to serve as excellent ligands in the field of 
coordination chemistry [7] [8] [9]. The azomethine group has worthwhile electron donating property [10] [11]. Therefore, it was used also to prepare many stable complexes with transition metal ions [12] [13]. Schiff bases are well known to have antibacterial [14] [15], antifungal [16] and antitumor [17] activities besides their other effective role in industry [18].

Azo-Schiff bases are a sort of chemicals possessing both the azo and azomethine groups and so combining the virtues of their precursors. These compounds are already synthesized within a two-step process: In the first step a coupling reaction of a diazonium ion with various substituted aromatic aldehydes is held to form the so called azo-aldehydes. In the second one the carbonyl group of this compound is condensed with alkyl or aryl amines using various chemical ways, such as refluxing [19] [20] [21] [22], fusion [23], irradiating in microwave reactors and others [24]. During the past forty years, numerous mono, bis, tris and tetra azo-Schiff bases were synthesized using traditional as well as green chemistry techniques. Subsequently a variety of researches have been published focusing on the biological activity of this sort of organic compounds [22] [25] [26] and considerable progress has been recorded considering their uses as ligands to form advantageous complexes [27] [28] [29] [30]; but a little work is recorded relating to their photophysical properties [23]. In this manuscript we are proceeding our initial studies [24] to synthesize new compounds of this type of organic molecule derived from the biological and photoactive acid-base indicator Congo red and some synthesized analogous compounds as a part of comprehensive strategy to design and prepare what we hope to be energy rich sensitizers in photochemical conversion systems or push pull compounds which may be applied in dye sensitized solar cells.

\section{Experimental}

\subsection{Materials and Methods}

The starting chemicals were of analytical grade and provided by Sigma-Aldrich, $\mathrm{BDH}$, Merck, and Scharlau companies; they were all used without any further purification. The uncorrected melting points of the synthesized compounds were determined using electrothermal melting point apparatus Stuart-SMP11. IR Spectra were obtained on a Nicolet $100 \mathrm{FT}-\mathrm{IR}$ as $\mathrm{KBr}$ discs in terms of frequency of absorption $\left(\mathrm{cm}^{-1}\right)$ in the range $400-4000 \mathrm{~cm}^{-1}$ and ${ }^{1} \mathrm{H}$ NMR spectra were run on a $400 \mathrm{MHz}$, DMSO- $\mathrm{d}^{6}$; TMS was used as the internal standard; DMSO- $d^{5}$ and $\mathrm{CDCl}_{3}$ were used as solvent. The electronic spectra were reported (recorded) in the range $200-800 \mathrm{~nm}$ using PG+ $92 \mathrm{UV}$-Visible spectrophotometer at a wavelength of maximum absorption $\left(\lambda_{\max }\right)$ in DMSO solutions at room temperature. Irradiations at microwave region of the electromagnetic radiation were carried out using BoMann microwave synthesizer.

\subsection{General Procedure for the Synthesis of the Compounds}

Synthesis of bis-Schiff bases of Congo red [Ia-g] (DMF method)

A finely ground mixture of ( $0.001 \mathrm{~mol}$ Congo red) and $0.002 \mathrm{~mol}$ of the appro- 
priate aromatic aldehyde were irradiated for 15 - 20 minutes moderately in a microwave reactor after adding (3 - 4) drops of DMF. The completion of the reaction and purity of the product was monitored using TLC strips. The product was washed with petroleum ether $(40-60){ }^{\circ} \mathrm{C}$, dried then recrystallized from ethanol.

Synthesis of bis-Schiff bases of Congo red (Glacial acetic acid method)

The same procedure was applied replacing DMF by $(6-8)$ drops of glacial acetic acid. The obtained results are given below:

Sodium 4-(((E)-benzylidene)amino)-3-((4-((1-(bezylideneamino)-4sulfonatonaphthalen-2-yl)diazenyl)-[1,1-biphenyl]-4-yl)diazenyl)naphthalene1-sulfonate (Ia)

Reddish Brown powder. Yield: 65\% (Glacial acetic acid), 72\% (DMF), M.P: $>300^{\circ}$ C. IR (ATR, cm ${ }^{-1}$ ): v 3062 (Ar. C-H), $1606(\mathrm{C}=\mathrm{N}), 1599$ (Ar. C=C), $1452(\mathrm{~N}=\mathrm{N})$. UV-Vis (DMSO, c $\left.10^{-4} \mathrm{~mol} \cdot \mathrm{L}^{-1}\right): \lambda_{\max }(\varepsilon) 225(12,000), 340(6020)$, 510 (8307) $\mathrm{nm}\left(\mathrm{mol}^{-1} \mathrm{~L} \mathrm{~cm}^{-1}\right) .{ }^{1} \mathrm{H}$ NMR (400 MHz, DMSO- $\left.d 6\right): \delta 6.71-7.95(\mathrm{~m}$, $28 \mathrm{H}, \mathrm{ArH}), 8.46(\mathrm{~s}, 2 \mathrm{H}, \mathrm{HC}=\mathrm{N}) \mathrm{ppm}$.

Sodium 3,3-([1] [1-biphenyl]-4,4-diylbis(diazene-2,1-diyl))bis(4-((4methoxybenzylidene)amino)naphthalene-1-sulfonate (Ib)

Green powder. Yield: 65\% (Glacial acetic acid), 68\% (DMF), M.P: $>300^{\circ} \mathrm{C}$. IR $\left(\mathrm{ATR}, \mathrm{cm}^{-1}\right.$ ): $v 3062$ (Ar. C-H), 2969; 2929 (Al. C-H), 1606 (C=N), 1599 (Ar. $\mathrm{C}=\mathrm{C}), 1452(\mathrm{~N}=\mathrm{N})$. UV-Vis (DMSO, c 10 $\left.{ }^{-4} \mathrm{~mol} \cdot \mathrm{L}^{-1}\right): \lambda_{\max }(\varepsilon) 225(11,963), 342$ (6130), 513 (8500) nm ( $\mathrm{mol}^{-1} \mathrm{~L} \mathrm{~cm}^{-1}$ ). ${ }^{1} \mathrm{H}$ NMR (400 MHz, DMSO-d6): $\delta 4.05$ (s, $\left.6 \mathrm{H} \mathrm{OCH}_{3}\right), 7.65-8.27(\mathrm{~m}, 26 \mathrm{H}, \mathrm{ArH}), 8.81(\mathrm{~s}, 2 \mathrm{H}, \mathrm{HC}=\mathrm{N}) \mathrm{ppm}$.

Sodium 4-(((E)-furan-2-ylmethylene)amino)-3-((4-((1-(((E)-furan-2ylmethylene)amino)-4-sulfonatonaphthalen-2-yl)diazenyl)-[1,1-biphenyl]4-yl)diazenyl)naphthalene-1-sulfonate (Ic)

Reddish Brown powder. Yield: 81\% (Glacial acetic acid), 73\% (DMF), M.P: $>300^{\circ}$ C. IR (ATR, cm ${ }^{-1}$ ): $v 3010$ (Ar. C-H), $1607(\mathrm{C}=\mathrm{N}), 1504$ (Ar. C=C), $1453(\mathrm{~N}=\mathrm{N})$. UV-Vis (DMSO, c $\left.10^{-4} \mathrm{~mol} \cdot \mathrm{L}^{-1}\right): \lambda_{\max }(\varepsilon) 221(12,500), 343$ (5980), $512(9100) \mathrm{nm}\left(\mathrm{mol}^{-1} \mathrm{~L} \mathrm{~cm}^{-1}\right) .{ }^{1} \mathrm{H}$ NMR (400 MHz, DMSO-d6): $\delta 6.8-8.2(\mathrm{~m}, 6 \mathrm{H}$ ArH furan), 7.6 - 8.9 (m, 18H ArH), $9.0(\mathrm{~s}, 2 \mathrm{H}, \mathrm{HC}=\mathrm{N}) \mathrm{ppm}$.

Sodium 3,3-([1,1-biphenyl]-4,4-diylbis(diazene-2,1-diyl))bis(4-((3-phenyl allylidene) amino) naphthalene-1-sulfonate. (Id)

Green powder. Yield: 83\% (Glacial acetic acid), 93\% (DMF), M.P: $>300^{\circ} \mathrm{C}$. IR $\left(\right.$ ATR, cm $\left.{ }^{-1}\right): v 3026$ (Ar. C-H), $1610(\mathrm{C}=\mathrm{N}), 1579$ (Ar. C=C), $1448(\mathrm{~N}=\mathrm{N})$. UV-Vis (DMSO, c $\left.10^{-4} \mathrm{~mol} \cdot \mathrm{L}^{-1}\right): \lambda_{\max }(\mathcal{E}) 226(12,100), 342(6590), 512(9000) \mathrm{nm}$ $\left(\mathrm{mol}^{-1} \mathrm{~L} \mathrm{~cm}{ }^{-1}\right) .{ }^{1} \mathrm{H}$ NMR (400 MHz, DMSO-d6): $\delta 3.03\left(\mathrm{~s}, 6 \mathrm{H} \mathrm{N}-\mathrm{CH}_{3}\right), 6.82-$ $8.91(\mathrm{~m}, 26 \mathrm{H} \mathrm{ArH}), 8.7(\mathrm{~s}, 2 \mathrm{H}, \mathrm{HC}=\mathrm{N}) \mathrm{ppm}$.

Sodium3,3-([1,1-biphenyl]-4,4-diylbis(diazene-2,1-diyl))bis(4-((4(dimethylamino) benzylidene) amino)naphthalene-sulfonate) (Ie)

Dark red powder. Yield: 59\% (Glacial acetic acid), 57\% (DMF), M.P: $>300^{\circ} \mathrm{C}$. IR (ATR, cm $\left.{ }^{-1}\right): v 3005$ (Ar. C-H), $1611(\mathrm{C}=\mathrm{N}), 1599(\mathrm{Ar} . \mathrm{C}=\mathrm{C}), 1439(\mathrm{~N}=\mathrm{N})$. UV-Vis (DMSO, c 10 $\left.0^{-4} \mathrm{~mol} \cdot \mathrm{L}^{-1}\right): \lambda_{\max }(\varepsilon) 225(12,100), 340(6600), 518(8950) \mathrm{nm}$ $\left(\mathrm{mol}^{-1} \mathrm{~L} \mathrm{~cm}^{-1}\right.$ ). ${ }^{1} \mathrm{H}$ NMR (400 MHz, DMSO-d6): $\delta 4.37(\mathrm{~s}, 12 \mathrm{H} \mathrm{NCH}$ ), $6.75-$ $8.03(\mathrm{~m}, 26 \mathrm{H}, \mathrm{ArH}), 8.45$ (s, 2H, HC=N) ppm. 
Sodium 3-((4((-sulfonato-1- $(((E)-3,4,5$-trimethoxybenzylidene) amino) naph-thalene-2-yl)diazenyl)-[1,1-biphenyl]-4-yl)diazenyl)-4-(((E)-3,4,5-tri methoxybenzylidene)amino)naphthalene-1-sulfonate (If)

Purple powder. Yield: $64 \%$ (Glacial acetic acid), 55\% (DMF), M.P: $>300^{\circ} \mathrm{C}$. IR $\left(\right.$ ATR, $\left.\mathrm{cm}^{-1}\right): v 3100($ Ar. C-H), $1616(\mathrm{C}=\mathrm{N}), 1584($ Ar. $\mathrm{C}=\mathrm{C}), 1458(\mathrm{~N}=\mathrm{N})$. UV-Vis (DMSO, c 10-4 mol. $\left.\mathrm{L}^{-1}\right): \lambda_{\max }(\varepsilon) 223(12,300), 342(6900), 519(8990) \mathrm{nm}$ $\left(\mathrm{mol}^{-1} \mathrm{~L} \mathrm{~cm}^{-1}\right)$ ) : ${ }^{1} \mathrm{H}$ NMR (400 MHz, DMSO-d6): $\delta 4.17$ (s, $\left.18 \mathrm{H} \mathrm{OCH}_{3}\right), 6.69$ $8.10(\mathrm{~m}, 22 \mathrm{H}, \mathrm{ArH}), 8.44(\mathrm{~s}, 2 \mathrm{H}, \mathrm{HC}=\mathrm{N}) \mathrm{ppm}$.

Sodium 4-(((E)-2-hydroxybenzylidene) amino)-3-((4- $(((E)$-2-hydroxyben-zylidene)amino)-4-sulfonatonaphthalene-2-yl)diazenyl)-[1,1-biphenyl]4-yl)naphthalene-1-sulfonate (Ig)

Red powder. Yield: $61 \%$ (Glacial acetic acid), 69\% (DMF), M.P: $>300^{\circ} \mathrm{C}$. IR $\left(\right.$ ATR, $\left.\mathrm{cm}^{-1}\right): v 3000($ Ar. C-H), $1601(\mathrm{C}=\mathrm{N}), 1599($ Ar. $\mathrm{C}=\mathrm{C}), 1460(\mathrm{~N}=\mathrm{N})$.

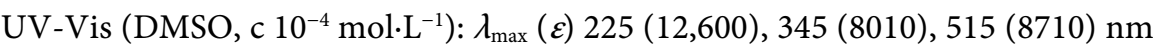
$\left(\mathrm{mol}^{-1} \mathrm{~L} \mathrm{~cm}^{-1}\right) .{ }^{1} \mathrm{H}$ NMR (400 MHz, DMSO- $\left.d 6\right): \delta 6.70-8.03(\mathrm{~m}, 22 \mathrm{H}, \mathrm{ArH})$, $8.30(\mathrm{~s}, 2 \mathrm{H}, \mathrm{HC}=\mathrm{N}), 11.7(\mathrm{~s}, 2 \mathrm{H}, \mathrm{OH}) \mathrm{ppm}$.

Preparation of [IIa-d]: The azo dyes were prepared according to a method similar to that described previously [24]. The obtained results are given below:

Sodium 4-((3-formyl-4-hydroxy-5-(phenyldiazenyl) phenyl)diazenyl) benzenesulfonate (IIa)

Orange powder. Yield: $66 \%$. M.P: $>300^{\circ} \mathrm{C}$. IR $\left(\mathrm{ATR}, \mathrm{cm}^{-1}\right): v 3400(\mathrm{O}-\mathrm{H})$, 3000 (Ar. C-H), $1660(\mathrm{C}=\mathrm{O}), 1579($ Ar. $\mathrm{C}=\mathrm{C}), 1463(\mathrm{~N}=\mathrm{N})$. UV-Vis (DMSO, c $\left.10^{-4} \mathrm{~mol} \cdot \mathrm{L}^{-1}\right): \lambda_{\max }(\varepsilon) 248(10,980), 353(2540), 410(2300) \mathrm{nm}\left(\mathrm{mol}^{-1} \mathrm{~L} \mathrm{~cm}^{-1}\right) .{ }^{1} \mathrm{H}$ NMR (400 MHz, DMSO- $d 6): \delta, 7.10-8.16(\mathrm{~m}, 11 \mathrm{H}, \mathrm{ArH}), 10.23(\mathrm{~s}, 1 \mathrm{H}, \mathrm{CHO})$, $11.20(\mathrm{~s}, 1 \mathrm{H}, \mathrm{OH}) \mathrm{ppm}$.

Sodium 4-((3-formyl-4-hydroxy-5-( $p$-tolyldiazenyl)phenyl)diazenyl)benzenesulfonate (IIb)

Orange powder. Yield: $63 \%$. M.P: $>300^{\circ} \mathrm{C}$. IR $\left(\mathrm{ATR}, \mathrm{cm}^{-1}\right): v 3467(\mathrm{O}-\mathrm{H})$, 3022 (Ar. C-H), 2967; 2929 (Al. C-H), $1660(\mathrm{C}=\mathrm{O}), 1580$ (Ar. C=C), 1452 $(\mathrm{N}=\mathrm{N})$. UV-Vis (DMSO, c 1.00.10 $\left.10^{-4} \mathrm{~mol} \cdot \mathrm{L}^{-1}\right): \lambda_{\max }(\varepsilon) 253(11,000), 344(2530)$, 420 (2305) nm $\left(\mathrm{mol}^{-1} \mathrm{~L} \mathrm{~cm}^{-1}\right) .{ }^{1} \mathrm{H}$ NMR $(400 \mathrm{MHz}, \mathrm{DMSO}-d 6): \delta 1.37(\mathrm{~s}, 3 \mathrm{H}$ $\left.\mathrm{CH}_{3}\right), 7.08$ - $8.10(\mathrm{~m}, 10 \mathrm{H}, \mathrm{ArH}), 10.20(\mathrm{~s}, 1 \mathrm{H}, \mathrm{CHO}), 11.15$ (s, 1H, OH) ppm.

Sodium 4-((4-clorophenyl)diazenyl)-5-formyl-4-hydroxyphenyl)diazenyl) benzenesulfonate (IIc)

Orange powder. Yield: 59\%. M.P: $>300^{\circ} \mathrm{C}$. IR $\left(\mathrm{ATR}, \mathrm{cm}^{-1}\right): v 3468(\mathrm{O}-\mathrm{H})$, 3040 (Ar. C-H), $1659(\mathrm{C}=\mathrm{O}), 1585$ (Ar. C=C), $1480(\mathrm{~N}=\mathrm{N})$. UV-Vis (DMSO, c $\left.10^{-4} \mathrm{~mol} \cdot \mathrm{L}^{-1}\right): \lambda_{\max }(\varepsilon) 251(11,008), 340(2560), 423(2389) \mathrm{nm}\left(\mathrm{mol}^{-1} \mathrm{~L} \mathrm{~cm}^{-1}\right) .{ }^{1} \mathrm{H}$ NMR (400 MHz, DMSO- $d 6): \delta, 6.98-8.10(\mathrm{~m}, 10 \mathrm{H}, \mathrm{ArH}), 10.1(\mathrm{~s}, 1 \mathrm{H}, \mathrm{CHO})$, 11.30 (s, $1 \mathrm{H}, \mathrm{OH}) \mathrm{ppm}$.

Sodium 4-((3-formyl-4-hydroxy-5-((4-nitrophenyl) diazenyl)phenyl) diazenyl) benzenesulfonate (IId)

Orange powder. Yield: $56 \%$. M.P: $>300^{\circ} \mathrm{C}$. IR $\left(\mathrm{ATR}, \mathrm{cm}^{-1}\right): v 3476(\mathrm{O}-\mathrm{H})$, $3101($ Ar. C-H), $1658(\mathrm{C}=\mathrm{O}), 1584($ Ar. $\mathrm{C}=\mathrm{C}), 1481(\mathrm{~N}=\mathrm{N})$. UV-Vis (DMSO, c $\left.10^{-4} \mathrm{~mol} \cdot \mathrm{L}^{-1}\right): \lambda_{\max }(\varepsilon) 250(11,100), 348(2605), 428(2400) \mathrm{nm}\left(\mathrm{mol}^{-1} \mathrm{~L} \mathrm{~cm}^{-1}\right) .{ }^{1} \mathrm{H}$ 
NMR (400 MHz, DMSO- $d 6): \delta, 7.00-8.14(\mathrm{~m}, 10 \mathrm{H}, \mathrm{ArH}), 10.3(\mathrm{~s}, 1 \mathrm{H}, \mathrm{CHO})$, $11.45(\mathrm{~s}, 1 \mathrm{H}, \mathrm{OH}) \mathrm{ppm}$.

Synthesis of the compounds [IIIa-d]

$0.001 \mathrm{~mol}$ of benzidine dissolved in $15 \mathrm{~mL}$ of absolute ethanol was added, in single portion, to a solution of $0.002 \mathrm{~mol}$ of compounds M11-14 in $15 \mathrm{~mL}$ absolute ethanol. The mixture was refluxed with stirring for 3-4 hours. The cooled residue was filtrated, left to dry at room temperature and recrystallized from ethanol. The obtained results are given below:

Sodium 4, 4-(((([1] [1-biphenyl]-4,4-diylbis(azanylylidene))bis (methany-lylidene))bis(4-hydroxy-5-(phenyldiazenyl)-3,1-phenylene))bis(diazene-2, 1-diyl))dibenzenesulfonate (IIIa)

Orange powder. Yield: $72 \%$. M.P: $>300^{\circ} \mathrm{C}$. IR $\left(\mathrm{ATR}, \mathrm{cm}^{-1}\right): v 3391(\mathrm{O}-\mathrm{H})$, $3000($ Ar. C-H), $1618(\mathrm{C}=\mathrm{N}), 1576($ Ar. $\mathrm{C}=\mathrm{C}), 1438(\mathrm{~N}=\mathrm{N})$. UV-Vis (DMSO, c $\left.10^{-4} \mathrm{~mol} \cdot \mathrm{L}^{-1}\right): \lambda_{\max }(\varepsilon) 252(9089), 295$ (5098), $385(6000) \mathrm{nm}\left(\mathrm{mol}^{-1} \mathrm{~L} \mathrm{~cm}^{-1}\right) .{ }^{1} \mathrm{H}$ NMR (400 MHz, DMSO-d6): $\delta 6.25-8.45(30 \mathrm{H}, \mathrm{ArH}), 9.25(\mathrm{~s}, 2 \mathrm{H}, \mathrm{HC}=\mathrm{N})$, 13.15 (s, 2H, OH) ppm.

Sodium 4, 4-(((([1] [1-biphenyl]-4, 4- diylbis (azanylylidene))bis (methany-lylidene))bis(4-hydroxy-5-(p-tolyldiazenyl)-3,1-phenylene))bis(diazene-2, 1-diyl))dibenzenesulfonate (IIIb)

Orange powder. Yield: 78\%. M.P: $>300^{\circ} \mathrm{C}$. IR $\left(\mathrm{ATR}, \mathrm{cm}^{-1}\right): \mathrm{v} 3396(\mathrm{O}-\mathrm{H})$, 2970; 2931 (Al. C-H), 3094 (Ar. C-H), $1620(\mathrm{C}=\mathrm{N}), 1487(\mathrm{~N}=\mathrm{N})$. UV-Vis (DMSO, c $\left.10^{-4} \mathrm{~mol} \cdot \mathrm{L}^{-1}\right): \lambda_{\max }(\varepsilon) 253$ (9100), 300 (4968), $390(5980) \mathrm{nm}\left(\mathrm{mol}^{-1} \mathrm{~L}\right.$ $\mathrm{cm}^{-1}$ ). ${ }^{1} \mathrm{H}$ NMR (400 MHz, DMSO- $\left.d 6\right): \delta 1.19\left(\mathrm{~s}, 6 \mathrm{H} \mathrm{CH}_{3}\right), 6.20-8.39(\mathrm{~m}, 28 \mathrm{H}$, ArH), 9.22 (s, 2H, HC=N) 13.84 (s, 2H, OH) ppm.

Sodium 4,4-(((([1] [1-biphenyl]-4,4-diylbis(azanylylidene))bis(methanylylidene))bis(5-((4-chlorophenyl)diazenyl)-4-hydroxy-3,1-phenylene))bis(diazene-2,1-diyl))dibenzenesulfonate (IIIc)

Orange powder. Yield: $66 \%$. M.P: $>300^{\circ} \mathrm{C}$. IR $\left(\mathrm{ATR}, \mathrm{cm}^{-1}\right): \mathrm{v} 3390(\mathrm{O}-\mathrm{H})$, 3035 (Ar. C-H), $1619(\mathrm{C}=\mathrm{N}), 1580$ (Ar. C=C), $1484(\mathrm{~N}=\mathrm{N}) . \mathrm{UV}-\mathrm{Vis}(\mathrm{DMSO}, \mathrm{c}$ $\left.10^{-4} \mathrm{~mol} \cdot \mathrm{L}^{-1}\right): \lambda_{\max }(\varepsilon) 253(9130), 300(5980), 395(6050) \mathrm{nm}\left(\mathrm{mol}^{-1} \mathrm{~L} \mathrm{~cm}^{-1}\right) .{ }^{1} \mathrm{H}$ NMR (400 MHz, DMSO-d6): $6.34-8.39(\mathrm{~m}, 28 \mathrm{H}, \mathrm{ArH}), 9.28(\mathrm{~s}, 2 \mathrm{H}, \mathrm{HC}=\mathrm{N})$ $13.01(\mathrm{~s}, 2 \mathrm{H}, \mathrm{OH}) \mathrm{ppm}$.

Sodium 4,4-(((([1] [1-biphenyl]-4,4-diylbis(azanylylidene))bis (methanylylidene))bis(4hydroxy-5-((4-nitrophenyl)diazenyl)-3,1-phenylene))bis(diazene-2,1-diyl))dibenzenesulfonate (IIId)

Orange powder. Yield: 80\%. M.P: $>300^{\circ} \mathrm{C}$. IR $\left(\mathrm{ATR}, \mathrm{cm}^{-1}\right)$ : v $3395(\mathrm{O}-\mathrm{H})$, $3062($ Ar. C-H), $1618(\mathrm{C}=\mathrm{N}), 1574($ Ar. $\mathrm{C}=\mathrm{C}), 1487(\mathrm{~N}=\mathrm{N})$. UV-Vis (DMSO, c $\left.10^{-4} \mathrm{~mol} \cdot \mathrm{L}^{-1}\right): \lambda_{\max }(\varepsilon) 250(9200), 300(6005), 405(6100) \mathrm{nm}\left(\mathrm{mol}^{-1} \mathrm{~L} \mathrm{~cm}^{-1}\right) .{ }^{1} \mathrm{H}$ NMR (400 MHz, DMSO- $d 6): \delta 1.19$ (s, 6 $\left.\mathrm{H} \mathrm{CH}_{3}\right), 6.20-8.39$ (m, 28H, ArH), 9.22 $(\mathrm{s}, 2 \mathrm{H}, \mathrm{HC}=\mathrm{N}) 13.84(\mathrm{~s}, 2 \mathrm{H}, \mathrm{OH}) \mathrm{ppm}$.

\section{Results and Discussion}

The synthesis of Schiff bases derivatives of the azo dye (Congo red) [Ia-g] were 
carried out as a single step reaction formulated in (Scheme 1) in moderate-good yield and in a short reaction time with a simple single step microwave irradiation experimental procedure. (Scheme 2) and (Scheme 3) summarize the multistep synthesis of the compounds [IIa-d] and [IIIa-d] respectively following the conventional chemical methods.

The validity of the target compounds was confirmed according to their FTIR, and NMR spectral data. Microwave assisted solid phase, mostly solvent free

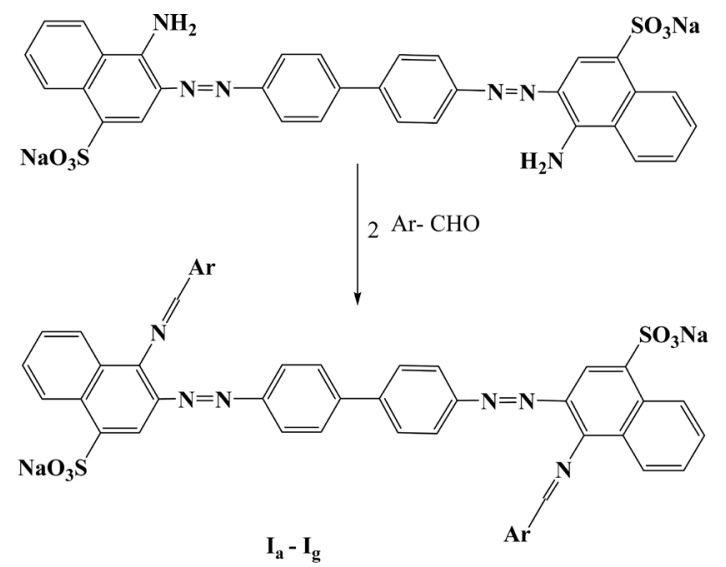

$\mathrm{Ar}=$ phenyl, 4-methoxyphenyl, furfuryl, cinommayl ,4-dimethyl amino phenyl, 3,4,5- trimethoxyphenyl, 2-hyroxy phenyl

Scheme 1. Preparation of the compounds (Ia-Ig).

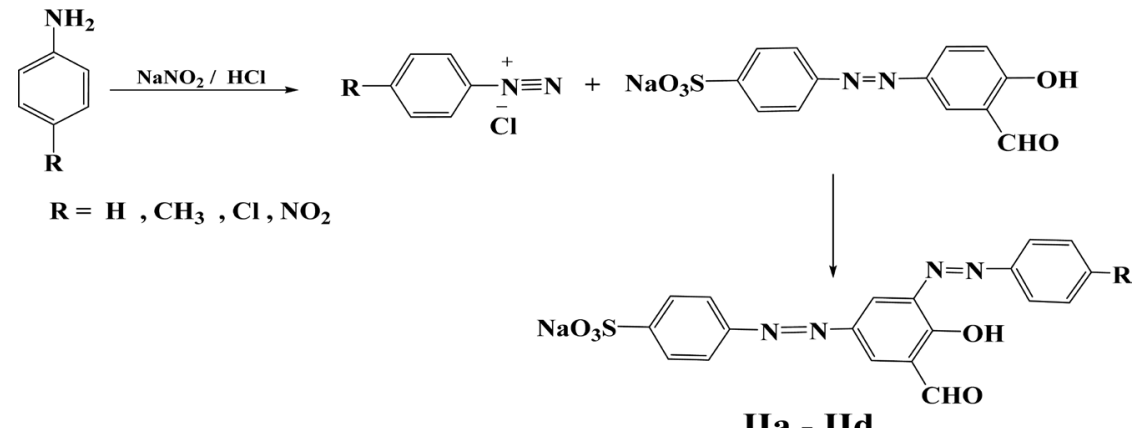

Scheme 2. Preparation of the compounds $\left[\mathrm{II}_{\mathrm{a}}-\mathrm{II}_{\mathrm{d}}\right]$.

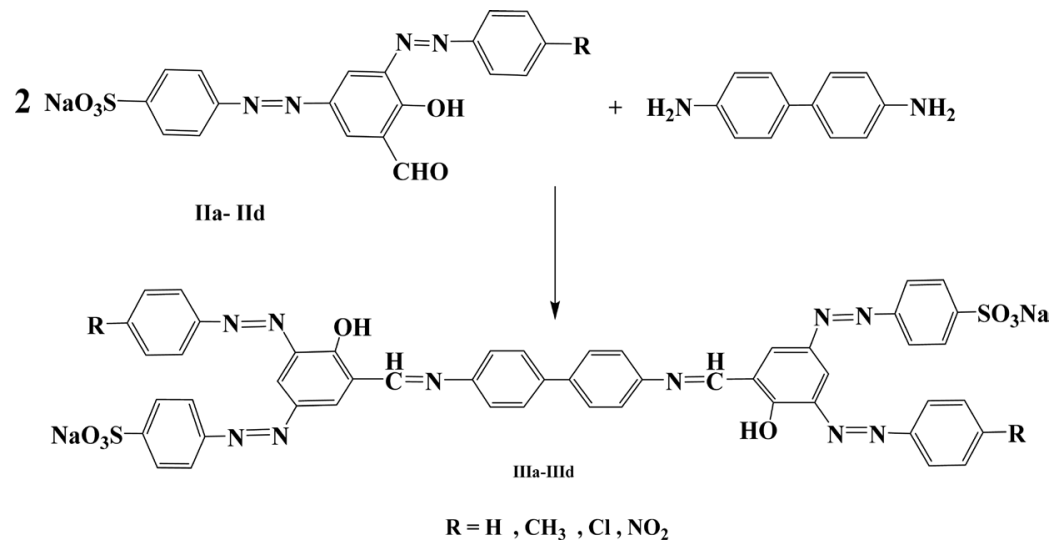

Scheme 3. Preparation of the compounds [IIIa-IIId]. 
synthesis was worked out in giving the desired Schiff base derivatives of Congo red in medium to high temperature heating in two separate trials. In the first trial drops of glacial acetic acid and in the second one few drops of DMF were used whereas, the starting materials were recovered on prolonged refluxing of the reaction mixtures in ethanol and dimethyl sulphoxide in the presence or absence of few drops of glacial acetic acid and piperidine separately. The difficulty of the condensation reaction held in reflux method is thought to be arising from the disability of both of the amino groups in the azo dye which are substituted at para position to the sulphonate groups deactivating them through their negative inductive and conjugation effect. Therefore the higher energy supplied by microwave irradiation is found to be very effective in the stimulation of the reaction through increasing the number of fruitful collisions according to Boltzmann diagram [31].

The difficulties faced in preparing of Schiff base of Congo red as well as the photochemical fragility thereof motivated us to imitate the resultant structure (bisazo-bisSchiff) by formulating new tetra azo-bis Schiff compounds (IIIa-IIId) in which the benzidine as the nucleus moiety, resembling the heart or the core of Congo red dye, was kept intact but the number and order of azomethine as well as the azo groups inside the molecule was reversed.

The synthesis of the structurally reversed analogous compounds (IIIa-IIId) was held through a two-stage reaction in which the well-known (sodium 4-((3formyl-4-hydroxyphenyl) diazenyl) benzenesulfonate, $\mathrm{Sb}$ ) was coupled with diazotization product of the para substituted aniline to give the diazo-aldehyde compounds (IIa-IId) in the end of the first stage. And in the second stage two moles of these compounds were condensed with single mole of benzidine on heating to reflux in ethanol.

\section{H-NMR Spectra}

The ${ }^{1} \mathrm{H}-\mathrm{NMR}$ spectra of the compounds [Ia-g] and [IIIa-d] showed the characteristic single signals at the range $(8.30$ - 9) ppm and $(9.22$ - 9.28) ppm respectively which are attributed to $(\mathrm{HC}=\mathrm{N})$ proton. The variation in the position of this signal is largely dependent on the nature of the substituents on the benzene ring. Multiple signals of the aromatic protons for all the synthesized compounds appeared at the range $(6.20-8.89) \mathrm{ppm}$. It was observed that the shape, location and the integration values of the signal of the aromatic protons are clearly affected by the entire structural environment of the examined molecules; the signals of the functional and the substituted groups were recorded in their expected positions.

\section{FTIR Spectra}

All the synthesized compounds showed the characteristic IR peaks that proved the presence of particular functional groups related to the compounds of each prepared scheme. For the compounds [Ia-Ig] the disappearance of the bands at $3313 \mathrm{~cm}^{-1}$ and $3264 \mathrm{~cm}^{-1}$ attributed to $\mathrm{NH}_{2}$ stretching frequency of the parent structure (Congo red) and the appearance of a new bands due to the azomethine 
groups $(\mathrm{CH}=\mathrm{N})$ at the range $(1601-1616) \mathrm{cm}^{-1}$ is a decisive evidence of the success of the condensation reaction. The azo group of the parent structure of Congo red appeared at the range $(1439-1460) \mathrm{cm}^{-1}$ influenced by the type of substuante (electrodonating or electrowithdrawing) on aromatic ring of the aldehyde precursor of the neighboring azomethine group. Other characteristic bands which are reported in the experimental parts confirmed our allegations.

For the compounds (IIa-IId) the IR band at $\left(1658\right.$ - 1660) $\mathrm{cm}^{-1}$ confirmed the presence of $(\mathrm{C}=\mathrm{O})$ of the aldehyde group. The band corresponding to the stretching vibration of the azo group $(\mathrm{N}=\mathrm{N})$ was observed in the region (1452 - 1481) $\mathrm{cm}^{-1}$. The variation in the range of azo group absorption is attributed to the diverse action of the substituent (mehyl, chloro, nitro groups) on the aniline precursor of the azo compound. Phenolic $(\mathrm{OH})$ stretching vibration appeared at (3460 - 3476) $\mathrm{cm}^{-1}$.

For the compounds [IIIa-IIId] $(=\mathrm{C}-\mathrm{H})$ stretching vibration of the aromatic rings were identified by their weak band at the region $(3000-3094) \mathrm{cm}^{-1}$. Stretching vibration of aliphatic and aromatic $(\mathrm{C}-\mathrm{H})$ appeared at $(2900) \mathrm{cm}^{-1}$ and (3010) $\mathrm{cm}^{-1}$ respectively. The band corresponding to the stretching vibration of the azo group $(\mathrm{N}=\mathrm{N})$ was observed in the region $(1438-1487) \mathrm{cm}^{-1}$ being affected by the variation of aromatic substituents. The azomethine groups were identified by their characteristic shapes (medium to strong) and location of their absorption bands at $(1618-1620) \mathrm{cm}^{-1}$, while the phenolic $(\mathrm{OH})$ groups were observed at (3391-3396) $\mathrm{cm}^{-1}$ being influenced by the six-membered intra-Hydrogen bonding ring formed with the nitrogen atom of the azomethine groups.

\section{$U V$-Visible Spectral Studies}

The UV-Vis absorption spectra of all of the synthesized compounds were recorded as solution in DMSO $\left(10^{-4} \mathrm{M}\right)$ at the range $(200-800) \mathrm{nm}$. For the bis azo-aldeyde compounds [IIa-IId], as previously stated [24], the first band at (248 - 253) $\mathrm{nm}$ is attributed to the $\pi-\pi^{*}$ transition of the whole molecule, the second band at $(340-353) \mathrm{nm}$ to the low $\pi-\pi^{*}$ transition and the third one at $(410-428)$ $\mathrm{nm}$ to the $n-\pi^{*}$ transition of both the azo and carbonyl groups [23]. The Congo red derivatives (bis Schiff-bis azo compounds [Ia-Ig] showed three absorption bands mainly. The first band appeared at the range $(221-226) \mathrm{nm}$ is attributed to the medium and low $\pi-\pi^{*}$ transition of the aromatic ring and heterocyclic moiety. This can be confirmed easily by the high values of molar transition coefficient $\left(\varepsilon ; \mathrm{mol} \cdot \mathrm{L}^{-1}\right)$ amounting to $(12,600)$. The second band appeared at $(340-$ 345) $\mathrm{nm}$ is due to the $n-\pi^{*}$ transition of the entire Schiff and azo conjugate system [32] [33]. The third band located at longer wavelength (510 - 519) nm, being more sensitive to the nature of substituent is assigned to the $\pi-\pi^{*}$ transition within the azo and azomethine groups involving charge transfer (CT) interaction through the whole molecule. The second and the third bands in the electronic spectrum of the compounds [IIIa-IIId] (tetra azo-bis Schiff) which were designed to be analogous to Schiff base derivatives of Congo red [Ia-Ig] were recorded at shorter wavelengths. The shorter energy charge-transfer absorption 
band in the above range might arrive from the reverse electron donation from the central azomethine groups towards the terminal azo groups potentiated by the negative inductive and conjugative effect of the sulfonates. This has reduced or totally prevented the extended conjugation through the whole molecule across the biphenyl group of the symmetrical molecule.

\section{Conclusion}

Here various methods and ways of reflux have been used to synthesize Schiff base derivative of the well-known Congo red dye; only irradiation in microwave reactor in a moderate to high temperature gave the desired product. Reversed analogous compounds that were designed and prepared, in a trial, to modify the photochemical fragility of Congo red led to, in contradiction to our adopted strategy, to the undesired bathochromatic shift of the maximum wavelength of the CT absorption band.

\section{Conflicts of Interest}

The authors declare no conflicts of interest regarding the publication of this paper.

\section{References}

[1] Muzael, M.H., AL-Zamili, T.F. and Shanan, H.K. (2008) Preparation, Characterization and Biological Activity of Some New Tetra-Azo Compounds. Journal of Thi-Qar Science, 1, 35-44. https://doi.org/10.32792/thi/sc/vol.1.is.2.05

[2] Jolly, V.S., Pathak, P.J. and Jain, R.J. (1993) Synthesis and Biological Activities of Some New Arylazopyrazoles. The Journal of the Indian Chemical Society, 70, 505507.

[3] Samadhiya, S. and Halve, A. (2001) Synthetic Utility of Schiff Bases as Potential Herbicidal Agents. Oriental Journal of Chemistry, 17, 119-122.

[4] Raj, H.D. and Patel, Y.S. (2015) Synthesis, Characterization and Antifungal Activity of Metal Complexes of 8-Hydroxyquinoline Based Azo Dye, Pelagia Research Library. Advances in Applied Science Research, 6, 119-123.

[5] Guerra, E., Liompart, M. and Garcia-Jares, C. (2018) Analysis of Dyes in Cosmetics: Challenges and Recent Development. Cosmetics, 5, 47.

https://doi.org/10.3390/cosmetics5030047

[6] Fardouly, J. and Vartanian, L.R. (2016) Social Media and Body Image Concerns: Current Research and Future Directions. Current Opinion in Psychology, 9, 1-5. https://doi.org/10.1016/j.copsyc.2015.09.005

[7] Nivorozhkin, A.L., Toftlund, H., Nivorozhkin, L.E., Kamenetskaya, I.A., Antsishkina, A.S. and Porai-Koshits, M.A. (1994) Synthesis and Structure of Tetracoordinated Nickel (II) Complexes of Deprotonated Chelated Aminoazo Ligands: X-Ray Crystal Structure of Bis[1-isopropyl-3-methyl-4-(4-methylphenylazo)-5-(4-methoxyphenylamidato)pyrazole] Nickel (II). Transition Metal Chemistry, 19, 319-324. https://doi.org/10.1007/BF00139103

[8] Abdallah, S.M. (2012) Metal Complexes of Azo Compounds Derived from 4-Acetamidophenol and Substituted Aniline. Arabian Journal of Chemistry, 5, 251-256. https://doi.org/10.1016/j.arabjc.2010.08.019 
[9] Oforka, N.C. and Mkpenie, V.N. (2007) A New Method of Synthesis of Azo Schiff Base Ligands with Azo and Azomrthine Donors: Synthesis of N-4-methoxybenzylidene2-(3-hydroxyphenylazo)-5-hydroxyaniline and Its Nickel (II) Complex. Chinese Journal of Chemistry, 25, 869-871. https://doi.org/10.1002/cjoc.200790159

[10] Bhattacharyya, P., Parr, J., Ross, A.T. and Slawin, A.M.Z. (1998) First Synthesis of a Unique Dilead Schiff Base Complex. Journal of the Chemical Society, Dalton Transactions, 19, 3149-3150. https://doi.org/10.1039/a806058d

[11] Abdul-Ghani, A.J. and Tapabashi, N.O. (2007) Light Induced Hydrogen Production from Ethanolic Aqueous Solution Sensitized by 2,4-Dimethoxy Benzylidine-2-hydroxy Aniline and Some of Its Metal Complexes. Ibn Al-Haitham Journal for Pure and Applied Science, 20, 128-145.

[12] Mohammed, H.A. and Taha, N.I. (2017) Microwave Preparation and Spectroscopic Investigation of Binuclear Schiff Base Metal Complexes Derived from 2,6-Diaminopyridine with Salicyladehyde. International Journal of Organic Chemistry, 7, 412-419. https://doi.org/10.4236/ijoc.2017.74033

[13] Al-Shareefi, A.N., Kadhim, S.H. and Jawad, W.A. (2013) Synthesis and Study of $\mathrm{Fe}(\mathrm{III}), \mathrm{Co}(\mathrm{II}), \mathrm{Ni}(\mathrm{II})$ and $\mathrm{Cu}(\mathrm{II})$ Complexes of New Schiff's Base Ligand Derived from 4-Amino Antipyrine. Journal of Applicable Chemistry, 2, 438-446.

[14] El-Masry, A.H., Fahmi, H.H. and Abdelwahed, S.H.A. (2000) Synthesis and Antimicrobial Activity of Some New Benzimidazole Derivatives. Molecules, 5, 1429 1438. https://doi.org/10.3390/51201429

[15] Rasheed, R.T. (2012) Synthesis of New Metal Complexes Derived from 5-Nitroso-8hydroxy Quinolone and Salicylidene p-imino Acetophenone with $\mathrm{Fe}(\mathrm{II}), \mathrm{Co}(\mathrm{II})$, $\mathrm{Ni}(\mathrm{II})$ and $\mathrm{Cu}(\mathrm{II})$ Ions. Journal of Al-Nahrain University, 15, 68-73. https://doi.org/10.22401/JNUS.15.4.08

[16] Singh, W.M. and Dash, B.C. (1998) Synthesis of Some New Schiff Bases Containing Thiazole and Oxazole Nuclei and Their Fungicidal Activity. Pesticides, 22, 33-37.

[17] Nofal, Z.M., El-Zahar, M.I. and Abd-El-Karim, S.S. (2000) Novel Coumarin Derivatives with Expected Biological Activity. Molecules, 5, 99-113.

https://doi.org/10.3390/50200099

[18] Tapabashi, N.O. (2016) Schiff Bases as Corrosion Inhibitors for Carbon Steel in $\mathrm{HCl}$ Solution. International Journal of Engineering and Advanced Research Technology, 2, 1-3.

[19] Khanmohammadi, H. and Darvishpour, M. (2009) New Azo Ligands Containing Azomethine Groups in the Pyridazine-Based Chain: Synthesis and Characterization. Dyes and Pigments, 81, 167-173. https://doi.org/10.1016/j.dyepig.2008.07.019

[20] Fekri, M.H., Darvishpour, M., Khanmohammadi, H. and Rashidipour, M. (2013) Synthesis and Biological Activity of a New Schiff Base Ligand Pyridazine Based. Journal of Chemical Health Risks, 3, 63-68.

[21] Eissa, H.H. (2013) Synthesis and Characterization of Azo-Schiff Bases and Study of Biological Activity. Journal of Current Research in Science, 1, 444-450.

[22] Azeez, H.N., Al-Kadhmi, A.A. and Tapabashi, N.O. (2019) Synthesis, Characterization and Biological Evaluation of Some Azo and Azo-Schiff Compounds. Kirkuk Journal of Scientific Researches, 14, 97-119. https://doi.org/10.32894/kujss.2019.14.1.8

[23] Tapabashi, N.O., Al-Janabi, K.M. and Mohammed, S.A. (2017) Thermal Performance, Photostability and UV-Visible Spectroscopic Studies of Some Synthesized Azo-Schiff and Bis-Azo-Schiff Bases. International Journal of Engineering and Advanced Research Technology, 3, 19-31. 
[24] Taha, N.I., Tapabashi, N.O. and El-Subeyhi, M.M. (2018) Green Synthesis of New Tetra Schiff Bases and Bis-Azo Bis-Schiff Bases Derived from 2,6-Diaminopyridine as Promising Photosensitizers. International Journal of Organic Chemistry, 8, 309318. https://doi.org/10.4236/ijoc.2018.83023

[25] Shreekanta, S.A., Venkatesh, T.V., Paramesshwara, P.N. and Shoba, K.S. (2014) Electrosynthesis, Electrochemical Behaviour, Antibacterial and Antifungal Activity of Novel Azo-Schiff's Bases. Indian Journal of Applied Research, 4, 91-95.

[26] Slassi, S., Fix-Tailler, A., Larcher, G., Amine, A. and El-Ghayoury, A. (2019) Imidazole and Azo-Based Schiff Bases Ligands as Highly Active Antifungal and Antioxidant Components. Heteroatom Chemistry, 2019, Article ID: 6862170. https://doi.org/10.1155/2019/6862170

[27] İspir, E. (2009) The Synthesis, Characterization, Electrochemical Character, Catalytic and Antimicrobial Activity of Novel, Azo-Contining Schiff Bases and Their Metal Complexes. Dyes and Pigments, 82, 13-19. https://doi.org/10.1016/j.dyepig.2008.09.019

[28] Mahdi, R.T., Ali, A.M. and Noaman, H.A. (2014) Preparation and Characterization of Some Metal Complexes with New Heterocyclic Schiff-Azo Ligand. Journal of Al-Nahrain University, 17, 51-58. https://doi.org/10.22401/JNUS.17.4.08

[29] Al-Hamdani, A.A.S., Balkhi, A., Falah, A. and Shaker, S.A. (2015) New Azo-Schiff Base Derived with $\mathrm{Ni}(\mathrm{II}), \mathrm{Pd}(\mathrm{II})$ and $\mathrm{Pt}(\mathrm{II})$ Complexes: Preparation, Spectroscopic Investigation, Structural Studies and Biological Activity. Journal of Chilean Chemical Society, 60, 2774-2785. https://doi.org/10.4067/S0717-97072015000100003

[30] Mahdi, S.M. and Ali, A.M. (2015) Preparation and Identification of New Azo-Schiff Ligands with Its Complexes. Iraqi National Journal of Chemistry, 15, 214-236.

[31] Atkins, P., DePaula, J. and Keeler, J. (2018) Atkins' Physical Chemistry. 11th Edition, Oxford University Press, Oxford.

[32] Shama, S.A., Kasem, M., Ali, E. and Moustafa, M.E. (2014) Synthesis and Characterization of Some New Azo Compounds Based on 2,4-Dihydroxy Benzoic Acid. Journal of Basic and Environmental Sciences, 1, 76-85.

[33] Lambert, J.B., Shurvell, H.F., Lighter, D.A. and Cooks, R.G. (2007) Organic Structural Spectroscopy. Prentice Hall, Upper Saddle River. 